\title{
Addition of silicon to boron foliar spray in cotton plants modulates the antioxidative system attenuating boron deficiency and toxicity
}

Jonas Pereira Souza Junior ( $\sim$ jonas.psj@hotmail.com )

Universidade Estadual Paulista Júlio de Mesquita Filho - Câmpus de Jaboticabal

https://orcid.org/0000-0002-3421-0706

Renato de Mello Prado

UNESP: Universidade Estadual Paulista Julio de Mesquita Filho

Cid Naudi Silva Campos

UFMS: Universidade Federal de Mato Grosso do Sul

Gilmar da Silveira Sousa Junior

UNESP: Universidade Estadual Paulista Julio de Mesquita Filho

Kevein Ruas Oliveira

Hungarian University of Agriculture and Life Sciences Institute of Horticulture: Magyar Agrar- es

Elettudomanyi Egyetem Kerteszettudomanyi Intezet

Jairo Osvaldo Cazetta

UNESP: Universidade Estadual Paulista Julio de Mesquita Filho

Priscila Lupino Gratão

UNESP: Universidade Estadual Paulista Julio de Mesquita Filho

\section{Research Article}

Keywords: Beneficial element, leaf spray, Gossypium hirsutum (cotton), nutritional disorder, nonenzymatic antioxidative mechanisms

Posted Date: February 25th, 2022

DOI: https://doi.org/10.21203/rs.3.rs-1127365/v1

License: (c) (i) This work is licensed under a Creative Commons Attribution 4.0 International License.

Read Full License 


\section{Abstract}

\section{Background:}

Boron (B) nutritional disorders, either deficiency or toxicity, may lead to an increase in reactive oxygen species production, causing damage to cells. Oxidative damage in leaves can be attenuated by supplying silicon ( $\mathrm{Si}$ ). The aim of this study was to assess assess the effect of increasing foliar B concentrations on cotton plants to determine whether adding $\mathrm{Si}$ to the spray solution promotes gains to correct deficiency and toxicity of this micronutrient by decreasing oxidative stress via synthetizing proline and glycine-betaine, thereby raising dry matter production.

\section{Results:}

B deficiency or toxicity increased $\mathrm{H}_{2} \mathrm{O}_{2}$ and MDA leaf content in cotton plants. $\mathrm{H}_{2} \mathrm{O}_{2}$ and MDA leaf content declined as a function of increased leaf $\mathrm{B}$ concentrations in the presence and absence of $\mathrm{Si}$. $\mathrm{B}$ deficiency stood out in $\mathrm{H}_{2} \mathrm{O}_{2}$ and MDA production compared to its toxicity. Proline and glycine-betaine content declined as a function of the rise in $\mathrm{B}$ concentration. In addition, production of these nonenzymatic antioxidant compounds was greater in plants under toxicity, in relation to deficient plants. Adding $\mathrm{Si}$ to the $\mathrm{B}$ spray solution reduced $\mathrm{H}_{2} \mathrm{O}_{2}$ and MDA content in the plants under nutrient deficiency or toxicity. Si reduced $\mathrm{H}_{2} \mathrm{O}_{2}$, primarily in B-deficient plants. Si also increased proline and glycine-betaine content, mainly in plants under B toxicity. Dry matter production of B-deficient cotton plants increased up to an application of $1.2 \mathrm{~g} \mathrm{~L}^{-1}$ of $\mathrm{B}$. The critical $\mathrm{B}$ level in the spray solution for deficiency and toxicity was observed at a concentration of 0.5 and $1.9 \mathrm{~g} \mathrm{~L}^{-1}$ of $\mathrm{B}$, respectively, in the presence of $\mathrm{Si}$, and 0.4 and $1.9 \mathrm{~g}$ $\mathrm{L}^{-1}$ of $\mathrm{B}$ without it. In addition, the presence of $\mathrm{Si}$ in the $\mathrm{B}$ solution raised dry matter production in all $\mathrm{B}$ concentrations evaluated in this study.

\section{Conclusion:}

Our findings demonstrated that adding Si to a B solution is important in the foliar spraying of cotton plants because it increases proline and glycine-betaine production and reduces $\mathrm{H}_{2} \mathrm{O}_{2}$ and MDA content, in addition to mitigating the oxidative stress in cotton plants under $\mathrm{B}$ deficiency or toxicity.

\section{Background}

Boron (B) foliar spraying is a common practice performed by cotton (Gossypium hirsutum L.) growers in different regions worldwide due to $B$ deficiency in different soils [1-3]. However, the difference between adequate concentration and $B$ toxicity is small $[1,4,5]$, and the toxic effect of this element can be verified in cotton plants when applied to leaves at high concentrations [3].

B nutritional disorder, either deficiency or toxicity, may lead to an increase in reactive oxygen species (ROS) production, causing oxidative damage to cells, as observed in beets [6] and field peas [7]. Oxidative stress occurs when there is an imbalance between ROS production and the antioxidant defense system 
(enzymatic and nonenzymatic), causing oxidative damage [8, 9]. However, the effects of B nutritional disorder on oxidative stress in plants remains unknown.

Although enzymatic antioxidant mechanisms are well known in cotton plants grown under abiotic stresses [10-12], studies on the nonenzymatic antioxidant defense systems are scarce, primarily those related to the action of proline [13] and glycine-betaine (GB) [14-16].

Oxidative damage in leaves may be attenuated by supplying silicon ( $\mathrm{Si})$, and has been widely reported in cotton plants grown under abiotic stresses [10-12]. The benefits of Si in mitigating B deficiency is due to the increase in chlorophyll content and photosynthetic efficiency [17], which improves the antioxidant defense system of the plant, as observed in other species [12, 18-21]. However, there is a lack of information indicating whether foliar Si spraying is sufficient to attenuate B deficiency and toxicity in cotton.

This raises an important question regarding the possibility of increasing the efficiency of B foliar spraying in order to mitigate the harmful effects of deficiency and or toxicity of this nutrient by including $\mathrm{Si}$ in the spray solution, although these elements must be chemically compatible. Therefore, the risk of $\mathrm{Si}$ polymerization in different nutrient solutions should also be considered.

It is important to test the hypothesis that raising B concentration in the spray solution to an adequate level reduces oxidative stress, with a consequent increase in cotton plant development. However, a low or high B concentration compromises plant development by increasing ROS synthesis, thereby causing oxidative damage. Considering the impact of B foliar spraying on cotton plants, the addition of Si to the B spray solution may have a combined effect (of the micronutrient and beneficial element) by attenuating oxidative stress and increasing plant development, mainly at insufficient or excessive B concentrations.

In this respect, a study was conducted to assess the effect of increasing foliar B concentrations on cotton plants to determine whether adding Si to the spray solution promotes gains to correct deficiency and toxicity of this micronutrient by decreasing oxidative stress via synthetizing proline and glycine-betaine, thereby raising dry matter production.

\section{Results}

\section{Control x Factorial}

Cotton plants grown without B deficiency (control) exhibited greater B accumulation, higher shoot dry matter production and lower B use efficiency, when compared to those from the factorial treatment. In addition, $\mathrm{Si}$ accumulation, oxidative stress (measured by $\mathrm{H}_{2} \mathrm{O}_{2}$ and MDA production), and the induction of the proline nonenzymatic antioxidant and GB systems were lowest in control plants (Table 1).

Table 1. Analysis of variance between control and treatments for leaf $B$ and Si accumulation, hydrogen peroxide $\left(\mathrm{H}_{2} \mathrm{O}_{2}\right)$, malondialdehyde (MDA), proline, glycine-betaine, dry weight and $\mathrm{B}$ use efficiency in the 
shoots of B-deficient cotton plants.

Accumulation

\begin{tabular}{|c|c|c|c|c|}
\hline & \multicolumn{2}{|l|}{ Boron } & \multicolumn{2}{|l|}{ Silicon } \\
\hline & \multicolumn{4}{|c|}{ 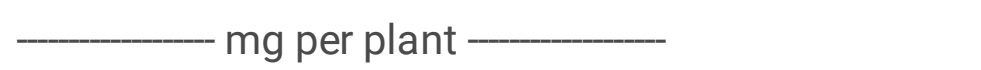 } \\
\hline F-test & \multicolumn{2}{|c|}{$257.1^{* *}$} & \multicolumn{2}{|c|}{$48.3^{* *}$} \\
\hline Control & \multicolumn{2}{|l|}{754.1} & \multicolumn{2}{|l|}{6.9} \\
\hline Factorial & \multicolumn{2}{|l|}{376.2} & \multicolumn{2}{|l|}{14.1} \\
\hline \multirow[t]{3}{*}{ CV (\%) } & \multicolumn{2}{|l|}{9.47} & \multicolumn{2}{|l|}{12.6} \\
\hline & $\mathrm{H}_{2} \mathrm{O}_{2}$ & MDA & Proline & Glycine-betaine \\
\hline & $\mu \mathrm{mol} \mathrm{g}{ }^{-1}$ & $\mathrm{~g} \mathrm{~g}^{-1}$ & $\mu \mathrm{mol} \mathrm{g}{ }^{-1}$ & $\mu \mathrm{g} \mathrm{g}^{-1}$ \\
\hline F-test & $173.20 * \star$ & $198.87 * *$ & $120.02 * *$ & $12.59 * *$ \\
\hline Control & 328.36 & 2.03 & 23.33 & 4.54 \\
\hline Factorial & 484.96 & 3.44 & 61.66 & 5.89 \\
\hline \multirow[t]{3}{*}{$\mathrm{CV}(\%)$} & 4.17 & 4.98 & 9.93 & 10.91 \\
\hline & \multicolumn{2}{|c|}{ Dry weight } & \multicolumn{2}{|c|}{ Boron use efficiency } \\
\hline & \multicolumn{2}{|l|}{ g } & \multicolumn{2}{|l|}{$\mathrm{mg} \mathrm{g}^{-1}$} \\
\hline F-test & \multicolumn{2}{|c|}{$78.82^{\star *}$} & \multicolumn{2}{|c|}{$38.68 * *$} \\
\hline Control & \multicolumn{2}{|l|}{6.50} & \multicolumn{2}{|l|}{0.04} \\
\hline Factorial & \multicolumn{2}{|l|}{4.78} & \multicolumn{2}{|l|}{0.10} \\
\hline CV (\%) & \multicolumn{2}{|l|}{6.46} & \multicolumn{2}{|l|}{10.4} \\
\hline
\end{tabular}

** - significant at $1 \%$ probability according to the F-test

Turbidity test of the spray solution and B and Si accumulation in cotton plants leaves

Adding $1.00 \mathrm{~g} \mathrm{~L}^{-1}$ of $\mathrm{Si}$ in the form of SiKE to the B spray solution $\left(2.50 \mathrm{~g} \mathrm{~L}^{-1}\right)$ did not increase the turbidity index of the solution, with an average value of $0.80 \mathrm{NDU}$ (Figure 1a). Adding $1.25 \mathrm{~g} \mathrm{~L}^{-1}$ of Si to the $B$ solution $\left(2.50 \mathrm{~g} \mathrm{~L}^{-1}\right)$ caused an exponential rise in the turbidity index, reaching $1.73 \mathrm{NDU}, 360$ minutes after preparation (Figure 1a). Increasing the Si concentration to $1.50 \mathrm{~g} \mathrm{~L}^{-1}$ resulted in the immediate polymerization of the solution, precluding reading the turbidity index. Therefore, the ideal $\mathrm{Si}$ concentration in the spray solution should be between 1.00 and $1.25 \mathrm{~g} \mathrm{~L}^{-1}$. 
In order to improve the accuracy of Si concentration in the solution, a second assessment was conducted, indicating that the maximum amount of $\mathrm{Si}$ (SiKE) to be added to the $\mathrm{B}$ solution ( $2.50 \mathrm{~g} \mathrm{~L}^{-1}$ of $\mathrm{B}$ ) is $1.00 \mathrm{~g}$ $\mathrm{L}^{-1}$ of $\mathrm{Si}$, without changing the turbidity index, with an average value of $0.80 \mathrm{NDU}$ (Figure 1b). The increase in concentration from 1.05 to $1.25 \mathrm{~g} \mathrm{~L}^{-1}$ of Si raised the turbidity index exponentially, with a maximum of $1.51 ; 1.55 ; 1.58 ; 1.69$ and 1.73 NDU after 360 minutes, for concentrations of $1.05 ; 1.10 ; 1.15$; 1.20 and $1.25 \mathrm{~g} \mathrm{~L}^{-1}$ of $\mathrm{Si}$, respectively.

With respect to the solution color, the $1.00 \mathrm{~g} \mathrm{~L}^{-1}$ of $\mathrm{Si}$ and $2.50 \mathrm{~g} \mathrm{~L}^{-1}$ of $\mathrm{B}$ mixture showed visible changes during the period assessed (Figure 2). Adding $1.25 \mathrm{~g} \mathrm{~L}^{-1}$ of Si resulted in the formation of polymers immediately after solution preparation (Figure 2a), evolving to a murky whitish color and gelatinous appearance after 360 minutes (Figure $2 b$ ). Adding $1.50 \mathrm{~g} \mathrm{~L}^{-1}$ of Si to the B solution ( $2.50 \mathrm{~g} \mathrm{~L}^{-1}$ of $\mathrm{B}$ ) resulted in immediate polymerization, forming a gel immediately after solution preparation (Figure 2a) and at 360 minutes (Figure 2b).

The second turbidity index assessment, with a higher number of Si concentrations, showed no change in the color of the $B$ spray solution $\left(2.50 \mathrm{~g} \mathrm{~L}^{-1}\right)$ with the addition of Si between 1.00 and $1.25 \mathrm{~g} \mathrm{~L}^{-1}$, except for polymer formation at a concentration of $1.25 \mathrm{~g} \mathrm{~L}^{-1}$, in the first $60 \mathrm{~min}$ after solution preparation (Figure $2 \mathrm{c}, \mathrm{d}$ ). At 120 minutes after B spray solution preparation (Figure 2e), adding 1.25 and $1.20 \mathrm{~g} \mathrm{~L}^{-1}$ of Si to the $\mathrm{B}$ solution changed the color of the solution, evolving to a whitish color.

Gelatinization started 180 minutes (Figure $2 f$ ) after spray solution preparation using the B solution mixed with $1.25 \mathrm{~g} \mathrm{~L}^{-1}$ of Si; at 300 minutes (Figure $2 \mathrm{~g}$ ) the B solution exhibited a gelatinous appearance when $1.20 \mathrm{~g} \mathrm{~L}^{-1}$ of Si was added, and a change in solution color with the addition of 1.15 and $1.10 \mathrm{~g} \mathrm{~L}^{-1}$ of Si.

At the end of the visual assessment (360 minutes) the B solution added with 1.25 and $1.20 \mathrm{~g} \mathrm{~L}^{-1}$ of Si exhibited a thick gelatinous appearance, the solutions with 1.15 and $1.10 \mathrm{~g} \mathrm{~L}^{-1}$ a whitish color, and those with $1.05 \mathrm{~g} \mathrm{~L}^{-1}$ of Si showed a slight color change, indicating the onset of visible polymerization.

B foliar spraying, in the absence or presence $\left(1.00 \mathrm{~g} \mathrm{~L}^{-1}\right)$ of $\mathrm{Si}$, caused a linear increase in $\mathrm{B}$ accumulation in cotton plants shoots, reaching a maximum of 906.8 and $901.0 \mathrm{mg}$ of $\mathrm{B}$ per plant, in the presence and absence of $\mathrm{Si}$, respectively (Figure $3 \mathrm{a}$ ). In addition, at low B concentrations ( 0.5 and $\left.1.00 \mathrm{~g} \mathrm{~L}^{-1}\right)$, adding Si to the $\mathrm{B}$ solution increased micronutrient absorption. The $\mathrm{Si}$ accumulation in the leaves of cotton plants also increased with the increasing in B concentration, reaching $39,11 \mathrm{mg}$ of Si per plant at $2,04 \mathrm{~g} \mathrm{~L}^{-1}$ of $B$ (Figure 3b)

\section{Oxidative stress, proline and glycine-betaine}

B deficiency $\left(0.0\right.$ and $0.5 \mathrm{~g} \mathrm{~L}^{-1}$ of $\mathrm{B}$ ) or toxicity $\left(2.5 \mathrm{~g} \mathrm{~L}^{-1}\right.$ of $\mathrm{B}$ ) increased $\mathrm{H}_{2} \mathrm{O}_{2}$ (Figure $4 \mathrm{a}$ ) and MDA content (Figure 4b). 
$\mathrm{H}_{2} \mathrm{O}_{2}$ content declined as a function of increased leaf $\mathrm{B}$ concentrations, with a minimum point at concentrations of 1.37 and $1.49 \mathrm{~g} \mathrm{~L}^{-1}$ of $\mathrm{B}$ in the presence and absence of $\mathrm{Si}$, respectively, for $\mathrm{H}_{2} \mathrm{O}_{2}$ (Figure 4a); and concentrations of 1.66 and $1.5 \mathrm{~g} \mathrm{~L}^{-1}$ of $\mathrm{B}$ in the presence and absence of Si, respectively, for MDA (Figure 4b). B deficiency stood out in $\mathrm{H}_{2} \mathrm{O}_{2}$ (Figure 4a) and MDA production (Figure 4b) compared to its toxicity. In the $0.0 \mathrm{~g} \mathrm{~L}^{-1}$ of $\mathrm{B}$ treatment, 539.1 and $767.3 \mu \mathrm{mol} \mathrm{g}-1 \mathrm{of}_{2} \mathrm{O}_{2}$ was produced in the presence and absence of $\mathrm{Si}$, respectively. These values represent an increase of 15 and $38 \%$ in the $\mathrm{H}_{2} \mathrm{O}_{2}$ produced by plants grown under $\mathrm{B}$ toxicity $\left(2.5 \mathrm{~g} \mathrm{~L}^{-1}\right)$, which obtained 467.3 and $555.4 \mu \mathrm{mol} \mathrm{g}^{-1}$, in the presence and absence of $\mathrm{Si}$, respectively (Figure $5 \mathrm{a})$. In the same treatment $\left(0.0 \mathrm{~g} \mathrm{~L}^{-1}\right.$ of $\left.\mathrm{B}\right), \mathrm{MDA}$ content was 4.2 and $5.1 \mathrm{~g} \mathrm{~g}^{-1}$, representing an increase of 50 and $30 \%$ compared to the $2.5 \mathrm{~g} \mathrm{~L}^{-1}$ of $\mathrm{B}$ treatment, which produced 2.8 and $3.9 \mathrm{~g} \mathrm{~g}^{-1}$ of MDA in the presence and absence of $\mathrm{Si}$, respectively (Figure 4b).

Proline (Figure 4c) and glycine-betaine (Figure 4d) content declined with a quadratic adjustment as a function of the rise in $B$ concentration. The minimum points for proline were observed with the addition of 1.14 and $1.03 \mathrm{~g} \mathrm{~L}^{-1}$ of $\mathrm{B}$, and a production of 42.6 and $39.7 \mu \mathrm{mol} \mathrm{g} \mathrm{g}^{-1}$ of proline, in the presence and absence of $\mathrm{Si}$, respectively (Figure $4 \mathrm{c}$ ). The minimum points for glycine-betaine occurred with 1.0 and 1.3 $\mathrm{g} \mathrm{L}^{-1}$ of $\mathrm{B}$, and a production of 5.2 and $5.5 \mathrm{~g} \mathrm{~g}^{-1}$, in the presence and absence of $\mathrm{Si}$, respectively (Figure $4 d)$.

In addition, production of these nonenzymatic antioxidant compounds was greater in plants under toxicity, with a proline content of 108.5 and $86.89 \mathrm{~g} \mathrm{~g}^{-1}$, an increase of 34 and $56 \%$ in relation to deficient plants, which produced 81.0 and $55.8 \mathrm{~g} \mathrm{~g}^{-1}$ in the presence and absence of Si, respectively (Figure 4c). Glycine-betaine content was also higher in plants under toxicity, primarily in the presence of $\mathrm{Si}$, with a production of $6.96 \mathrm{~g} \mathrm{~g}^{-1}$ of glycine-betaine, a $21 \%$ increase in relation to nutrient-deficient plants, which produced $5.74 \mathrm{~g} \mathrm{~g}^{-1}$ of glycine-betaine (Figure $4 \mathrm{~d}$ ). In the absence of $\mathrm{Si}$, the increase was $4 \%$ in plants under toxicity $\left(6.42 \mathrm{~g} \mathrm{~g}^{-1}\right)$ when compared to those with nutrient deficiency $\left(6.18 \mathrm{~g} \mathrm{~g}^{-1}\right)$.

Adding $\mathrm{Si}$ to the $\mathrm{B}$ spray solution reduced $\mathrm{H}_{2} \mathrm{O}_{2}$ (Figure $4 \mathrm{a}$ ) and MDA content (Figure $4 \mathrm{~b}$ ) in the plants under nutrient deficiency ( 0.0 and $0.5 \mathrm{~g} \mathrm{~L}^{-1}$ of $\mathrm{B}$ ) and those under toxicity $\left(2.5 \mathrm{~g} \mathrm{~L}^{-1}\right.$ of $\left.\mathrm{B}\right)$. Si reduced $\mathrm{H}_{2} \mathrm{O}_{2}$, primarily in B-deficient plants, with a production of 539.1 and $402.2 \mu \mathrm{mol} \mathrm{g}^{-1}$ for 0.0 and $0.5 \mathrm{~g} \mathrm{~L}^{-1}$ of $\mathrm{B}$, respectively (Figure 4a). These values are 29 and $24 \%$ lower compared to $\mathrm{H}_{2} \mathrm{O}_{2}$ production in the absence of the element, which was 767.3 and $532.9 \mu \mathrm{mol} \mathrm{g}^{-1}$ for 0.0 and $0.5 \mathrm{~g} \mathrm{~L}^{-1}$ of B, respectively (Fig. $4 \mathrm{~b}$ ). Si also increased proline (Figure $4 \mathrm{c}$ ) and glycine-betaine content (Figure $4 \mathrm{~d}$ ), mainly in plants under $B$ toxicity $\left(2.5 \mathrm{~g} \mathrm{~L}^{-1}\right.$ of $\left.\mathrm{B}\right)$.

\section{Dry matter production}

Dry matter production of B-deficient cotton plants increased up to an application of 1.2 and $1.1 \mathrm{~g} \mathrm{~L}^{-1}$ of $\mathrm{B}$, with maximum production of 6.1 and $5.4 \mathrm{~g}$ in the presence and absence of $\mathrm{Si}$, respectively (Figure $5 \mathrm{a}$ ). 
The critical B level in the spray solution was established in cotton plants for deficiency and toxicity, with a $10 \%$ decline in total dry matter produced at a concentration of 0.5 and $1.9 \mathrm{~g} \mathrm{~L}^{-1}$ of $\mathrm{B}$, respectively, in the presence of $\mathrm{Si}$, and 0.4 and $1.9 \mathrm{~g} \mathrm{~L}^{-1}$ of $\mathrm{B}$ without it. In addition, the presence of $\mathrm{Si}$ in the $\mathrm{B}$ solution raised dry matter production in all B concentrations evaluated in this study (Figure 5a).

The efficiency of shoot B application in the absence or presence of Si (Figure 5b) caused a linear reduction with an increase in the $B$ concentration applied. The presence of $\mathrm{Si}$ in the $\mathrm{B}$ solution raised $\mathrm{B}$ use efficiency at concentrations of 1.5 and $2.5 \mathrm{~g} \mathrm{~L}^{-1}$.

\section{Discussion}

The main drawback of $\mathrm{Si}$ in solution is polymerization, which has significant implications, since it leads to the formation of insoluble silicon dioxide $\left(\mathrm{SiO}_{2}\right)$, compromising the element's benefits to plants. Silanol groups are formed during polymerization and monosilicic acid condensation. Next, the supersaturated solution of acid is converted into its polymer form, forming insoluble spherical colloidal particles [22] that in turn form long-chain networks, inducing visible changes in the solution from translucid to opaque or murky (Fig. 2).

Assessing the turbidity index made it possible to detect color change in the silicon solution before the visible phase (Figure 1). It was evident that even at the high B concentration $\left(2.5 \mathrm{~g} \mathrm{~L}^{-1}\right)$, a maximum of $1.00 \mathrm{~g} \mathrm{~L}^{-1}$ of $\mathrm{Si}$ can be added to the B solution without significant polymerization. The stability of this silicon solution is partially explained by the stabilizing effect of sorbitol present in the product to guarantee successful Si foliar application [23]. This is because adding stabilizers is an efficient alternative to reduce polymerization of the silicon solution, thereby increasing Si leaf absorption in several crops $[7,24,25]$, including cotton plants $[17,23]$.

The low Si polymerization in the $B$ solution $\left(2.50 \mathrm{~g} \mathrm{~L}^{-1}\right.$ of $\left.\mathrm{B}\right)$ can be confirmed in the present study by the efficiency of B foliar spraying, evidenced by the increased B and Si content in the shoots of cotton plants (Figure 3). Sorbitol has another effect in Si leaf absorption since it decreases the deliquescence point of the drops deposited onto the leaf surface, thereby lowering the rate of water evaporation (Kubicki and Heaney, 2003), and favoring leaf absorption [27].

Adding $\mathrm{Si}$ to the $\mathrm{B}$ solution reduced $\mathrm{H}_{2} \mathrm{O}_{2}$ (Figure $4 \mathrm{a}$ ) and MDA production (Figure $4 \mathrm{~b}$ ). This beneficial effect of $\mathrm{Si}$ is demonstrated by its role in increasing the activity of the nonenzymatic defense system, such as proline (Figure 4c) and glycine-betaine (GB) (Figure 4d).

Proline has an important function in enhancing plant tolerance to abiotic stresses and reducing oxidative damages since it raises the redox potential, which is essential to the antioxidant defense of plants, replenishing the supply of $\mathrm{NADP}^{+}$[28]. $\mathrm{NADP}^{+}$is generated during proline synthesis and its oxidation results in the production of NADPH, acting as a buffering agent of the redox potential inside the cell [29], binding to and easily neutralizing ROS [30]. Moreover, plants under stressful conditions exhibit an 
increase in proline content, given the excess production of low molecular weight compounds, highly soluble as compatible organic solutes.

$\mathrm{GB}$, in turn, contributes to maintaining structural integrity and cellular function, which is possible due to its interaction with the hydrophilic and hydrophobic domains of protein and membrane complexes [16]. In addition, GB reduces ROS levels, contributing to their homeostasis [31] and inducing gene expression related to stress defense mechanisms via the octadecanoid pathway [32]. The action mechanisms of GB in cotton plants are not well known. However, Hamani et al. [15] found that the exogenous application of GB in this plant species grown under salt stress decreases MDA production and helps to activate different antioxidant enzymes.

Si action mechanisms in the biosynthesis of these nonenzymatic antioxidant compounds remain unclear and controversial in the literature. Some studies indicate that after applying this element there is a reduction in proline [33-35] and GB production [35], thereby decreasing cell injury due to the effect of Si as a protective agent and the activation of defense mechanisms against cell damage. On the other hand, other studies showed that Si applications activate the enzymatic defense mechanisms [12], especially their nonenzymatic counterparts [18], given the increase in proline and GB production due to the protective/activating function of $\mathrm{Si}$, as demonstrated in this experiment.

In the present study, we showed that Si modulates the nonenzymatic antioxidant system, thereby attenuating nutritional stress and favoring an increase in the dry matter production of cotton plants grown under B deficiency or toxicity (Figure 5a). Therefore, this antioxidant role of Si could explain its benefits in B-deficient cotton plants reported by Souza Júnior et al. [17] and Barros et al. [36], who attributed it to the increased chlorophyll content and photosynthetic efficiency.

It is known that the toxicity of a chemical element promoted by foliar application is relatively rapid and that there are few strategies to reverse leaf damage [37]. Therefore, our findings showed that leaf damage can be mitigated by adding Si to the B solution during spraying, demonstrating that Si has a high potential in reducing the oxidative stress. This likely favored the plant's metabolism, thereby increasing its capacity in converting micronutrient into biomass, since Si increased B use efficiency at the highest concentrations applied to the leaves (Figure 5b).

The present study revealed the relationship between $\mathrm{B}$ and $\mathrm{Si}$ in cotton plants, proposing foliar spraying in B-deficient areas at the critical concentration of $0.5 \mathrm{~g} \mathrm{~L}^{-1}$ of $\mathrm{B}$ with the addition of $1.0 \mathrm{~g} \mathrm{~L}^{-1}$ of Si, and demonstrating that a $B$ concentration above $1.9 \mathrm{~g} \mathrm{~L}^{-1}$ may be toxic to cotton plants. This information regarding the interaction of these elements for better foliar spraying efficiency in cotton plants has global implications, given that several growing regions of this crop have reported B deficiency.

\section{Conclusions}

In conclusion, $\mathrm{B}$ foliar spraying up to a concentration of $1.1 \mathrm{~g} \mathrm{~L}^{-1}$ in the absence of $\mathrm{Si}$, or $1.2 \mathrm{~g} \mathrm{~L}^{-1}$ in the presence of this element $\left(1.0 \mathrm{~g} \mathrm{~L}^{-1}\right)$, results in maximum dry matter production, indicating that it is 
efficient in attenuating the harmful effects of B deficiency and that a concentration of $2.5 \mathrm{~g} \mathrm{~L}^{-1}$ causes severe toxicity in the plants.

Our findings demonstrated that adding $\mathrm{Si}$ to a B solution is important in the foliar spraying of cotton plants because it increases proline and glycine-betaine production and reduces $\mathrm{H}_{2} \mathrm{O}_{2}$ and MDA content, in addition to mitigating the oxidative stress in cotton plants under $\mathrm{B}$ deficiency or toxicity.

\section{Methods}

\section{Growing conditions}

The experiment with cotton (Gossypium hirsutum L.) was conducted between January and May 2019 in a greenhouse at the São Paulo State University (UNESP), Jaboticabal, Brazil. Seeds of the cultivar 954 GLT were used, commercially acquired from BASF, as it is a cultivar that presents consistent results in different regions and is highly adaptable to producing regions in Brazil. Seeds of cultivar $954 \mathrm{GLT}$, commercially obtained from BASF, were used as it is a cultivar that presents consistent results in different regions and is highly adaptable to cotton producing regions in Brazil. Plants were grown in a soilless cultivation system. Relative humidity $(78.4 \pm 4.4 \%)$, maximum $\left(35.1 \pm 6.3^{\circ} \mathrm{C}\right)$ and minimum temperature $\left(22.0 \pm 3.2^{\circ} \mathrm{C}\right)$ were recorded with a thermometer hydrometer in the greenhouse during the experimental period (Figure 6).

Cotton seeds were sown into trays containing sand previously washed with water and $\mathrm{HCl}$ solution $(0.1$ M). After germination, four seedlings were transplanted to plastic pots with a $7 \mathrm{dm}^{3}$ capacity (upper diameter: $16 \mathrm{~cm}$; lower diameter: $11 \mathrm{~cm}$; height: $33 \mathrm{~cm}$ ), filled with $6 \mathrm{dm}^{3}$ of sand previously washed. Thinning was performed with the plants in the vegetative growth stage F2 (two fully developed leaves), maintaining one plant per pot, which was considered as the experimental unit.

A complete nutrient solution was applied to the plants in the vegetative stage F4 (four fully developed leaves) [38]. The nutrient solution was prepared with Fe-EDDHMA as the iron source; pH between 5.5 and 6.5 , adjusted with $\mathrm{NaOH}(1 \mathrm{M})$ or $\mathrm{HCl}(1 \mathrm{M})$ solution, and with a reduction only in $\mathrm{B}$ concentration (from 46.2 to $33.7 \mu \mathrm{mol} \mathrm{L}^{-1}$ ), in order to cause moderate B deficiency in cotton plants grown in a soilless system [17].

The nutrient solution was applied for seven days at $20 \%$ of its total concentration, as indicated by Hoagland and Arnon [38]. After this period, the concentration was increased to $40 \%$ for one week and then to $60 \%$, which was maintained until the end of the experimental period.

The substrate was drained once a week to eliminate excess of salts, with $700 \mathrm{~mL}$ of deionized water being added to the substrate of each pot to drain the nutrient solution, which was then discarded. After 2 hours, a new nutrient solution was provided to the plants and during the rest of the growth cycle the nutrients required for plant development were supplied regularly. 


\section{Experimental design and treatments}

The experiment was carried out under a completely randomized blocks design $(5 \times 2+1)$ with four repetitions. The following treatments were applied: five foliar $B$ concentrations $(0.0 ; 0.5 ; 1.0 ; 1.5$ and $2.5 \mathrm{~g}$

$\mathrm{L}^{-1}$ of $\left.\mathrm{B}\right)$, absence and presence $\left(1.00 \mathrm{~g} \mathrm{~L}^{-1}\right)$ of $\mathrm{Si}$; and one control treatment with no micronutrient deficiency, adding $46.2 \mu \mathrm{mol} \mathrm{L}^{-1}$ of $\mathrm{B}$ to the nutrient solution during the entire experimental period.

B concentrations in the spray solution were $0 \% ; 33 \% ; 66 \% ; 100 \%$ and $166 \%$ of the concentration recommended by Görmüs [39], where the author indicates foliar spraying of $1.5 \mathrm{~g} \mathrm{~L}^{-1}$ of B for cotton plants grown in a micronutrient-deficient environment.

The Si concentration to be mixed with the B solution was defined based on the visual evaluation of the final solution to avoid using it with evidence of polymerization, which was measured by using the turbidity index.

\section{Turbidity index of the B+Si spray solution}

To prepare the solution, boric acid (B: $175 \mathrm{~g} \mathrm{~kg}^{-1}$; density: $1.43 \mathrm{~g} \mathrm{~cm}^{-3}$; solubility in water at $20^{\circ} \mathrm{C}: 47.2 \mathrm{~g} \mathrm{~L}^{-}$ ${ }^{1}$ ) was used as the $\mathrm{B}$ source, with the $\mathrm{pH}$ of the $\mathrm{B}$ spray solution adjusted to 9.0 using an $\mathrm{NaOH}$ solution (1M). The Si source consisted of potassium silicate stabilized with sorbitol (SiKE; Si: $115 \mathrm{~g} \mathrm{~L}^{-1} ; \mathrm{K}_{2} \mathrm{O}$ : $113.85 \mathrm{~g} \mathrm{~L}^{-1}$; sorbitol: $\left.100 \mathrm{~mL} \mathrm{~L}^{-1} ; \mathrm{pH}: 12.0\right)$. A potassium solution was also prepared with $47 \mathrm{mg} \mathrm{L}^{-1}$ of $\mathrm{K}_{\text {, }}$ in the form of $\mathrm{KCl}$, to balance the macronutrient between treatments.

Two turbidity index assessments of the B+Si spray solution were performed to determine the homogeneity of the Si solution, since an increase in its value would indicate advancing Si polymerization. For this test, the $B$ concentration of the solution was fixed at $2.5 \mathrm{~g} \mathrm{~L}^{-1}$, the highest concentration studied in this experiment. Assessment I consisted of adding Si to the B solution at concentrations of $1.00 ; 1.25$ and $1.50 \mathrm{~g} \mathrm{~L}^{-1}$ of $\mathrm{Si}$; assessment II used a B mixture $\left(2.5 \mathrm{~g} \mathrm{~L}^{-1}\right)$ with smaller intervals between $\mathrm{Si}$ concentrations of $1.00 ; 1.05 ; 1.10 ; 1.15 ; 1.20$ and $1.25 \mathrm{~g} \mathrm{~L}^{-1}$ in order to increase the accuracy of the concentration in the spray solution. In both assessments, SiKE was used as Si source and $\mathrm{H}_{3} \mathrm{BO}_{4}$ as $\mathrm{B}$ source in the solution with a final volume of $50 \mathrm{~mL}, \mathrm{pH}$ adjusted to $9.05 \pm 0.02$ using a solution of $\mathrm{HCl}$ ( 1 $\mathrm{M})$ or $\mathrm{NaOH}(1 \mathrm{M})$ at a temperature of $20^{\circ} \mathrm{C}$, with three repetitions. After the spray solution was prepared, the turbidity index was measured with a Tecnopon ${ }^{\circledR}$ microprocessed turbidity meter (model TB1000) at 0 ; $30 ; 60 ; 90 ; 120 ; 180 ; 240 ; 300$ and 360 minutes, and photographs were taken using a camera with $9238 \mathrm{x}$ 6928-pixel resolution.

All beakers with the different solutions were placed in front of a completely black background and were then photographed. The images were adjusted using Adobe Photoshop ${ }^{\circledR}$ in order to improve the contrast with the black background without changing $\mathrm{B}+\mathrm{Si}$ solution color.

\section{Foliar application in the treatments}


The solution was prepared according to the different treatments and immediately applied to the plants with a manual sprayer until run-off, in order to cover all the leaves of the plants. A $5.0 \mathrm{~mL}$ volume of the solution was applied to each pot. Sprayings occurred between 7 and 8 am, starting with cotton plants in the reproductive stage B1 (first completely developed flower bud), with four foliar applications four days apart. Temperature and relative humidity were measured by a thermometer hydrometer during applications, resulting in a temperature between 20 and $23^{\circ} \mathrm{C}$, and relative humidity above $85 \%$, conditions favorable for foliar spraying [27].

During foliar applications, all pots were covered with cotton to avoid any dropping or spillage from the plant shoot after being sprayed with the B+Si solution to the substrate, in order to guarantee that the elements absorption was totally foliar.

\section{Non-enzymatic antioxidant system (proline and glycine-betaine)}

Leaves were collected three weeks after foliar application of the B+Si mixture, and immediately frozen in liquid nitrogen, then placed in a freezer at $-80^{\circ} \mathrm{C}$ to assess the oxidative stress.

The rest of the shoot (branches and stem) was also collected, washed with water, detergent solution $(0.1 \%), \mathrm{HCl}$ solution $(0.1 \%)$ and deionized water, being then placed in a forced air circulation oven at $65 \pm$ $5^{\circ} \mathrm{C}$ until constant mass. Next, the branches and stems were weighed, ground in a Wiley mill and stored for subsequent assessments.

In order to assess the oxidative stress, malondialdehyde (MDA) and hydrogen peroxide $\left(\mathrm{H}_{2} \mathrm{O}_{2}\right)$ content were determined on the leaves.

Initially, 0.4 grams of the frozen plant material was weighed, maintained at $-80^{\circ} \mathrm{C}$, and ground with $20 \%$ $(\mathrm{m} / \mathrm{v})$ polyvinylpyrrolidone and $0.1 \%$ trichloroacetic acid (TCA). The material was centrifuged at 11,000 rotations per minute at $4^{\circ} \mathrm{C}$ for 10 minutes. The supernatant was separated into Eppendorf tubes containing a $20 \%$ TCA solution and $5 \%$ thiobarbituric (TBA) acid. The samples were incubated in a water bath for 30 minutes at $95^{\circ} \mathrm{C}$, transferred to an ice bath for 10 minutes to stop the reactions, and then centrifuged at 11,000 rotations per minute at $4^{\circ} \mathrm{C}$ for 10 minutes. Next, the samples were read in a spectrophotometer at wavelengths between 535 and 600 nanometers and MDA calculated using an extinction coefficient of $1.5510^{-5} \mathrm{~mol}^{-1} \mathrm{~cm}^{-1}$ [40].

$\mathrm{H}_{2} \mathrm{O}_{2}$ content was determined by homogenizing the frozen ground plant tissues with $0.1 \%$ TBA, followed by centrifugation at 11,000 rotations per minute at $4^{\circ} \mathrm{C}$ for 10 minutes. The supernatant was also transferred to Eppendorf tubes containing a buffer solution $(\mathrm{pH} \mathrm{7.5)}$ and potassium iodine and then incubated for one hour in an ice-filled container. Next, spectrophotometric readings were conducted at a wavelength of $390 \mathrm{~nm}$, in line with the methodology described by Alexieva et al. [41].

Proline content was determined using the method proposed by Bates et al. [42]. Plant material was defrosted at ambient temperature and $0.5 \mathrm{~g}$ of fresh matter was macerated in liquid nitrogen and 
subsequently $2 \mathrm{~mL}$ of sulfosalicylic acid was added, followed by adding more $8 \mathrm{~mL}$ of the same reagent. The grinded material was doubly filtered in a glass funnel using filter paper. After filtering, $1 \mathrm{~mL}$ of glacial acetic acid, $1 \mathrm{~mL}$ of ninhydrin acid and $1 \mathrm{~mL}$ of plant extract were pipetted into a glass test tube. The tubes were then agitated and placed in a water bath at $100^{\circ} \mathrm{C}$ for 1 hour and then into an ice bath to stop the reaction. Toluene was added $(2 \mathrm{~mL})$, followed by a 20 -second agitation. Spectrophotometric readings were performed at $520 \mathrm{~nm}$, adding $0.5 \mathrm{~mL}$ of the supernatant in a quartz cuvette.

Glycine-betaine content was determined according to the methodology proposed by Grieve and Grattan [43]. For that, $1 \mathrm{~g}$ of frozen plant material was placed in paper bags and dried in a forced air circulation oven at $80^{\circ} \mathrm{C}$ for four days, then manually grinded in a crucible. Extracts were prepared by adding $5 \mathrm{~mL}$ of deionized water to $0.125 \mathrm{~g}$ of macerated material, which remained under agitation for 24 hours at $25^{\circ} \mathrm{C}$. The extracts were mixed at $1: 1$ with $\mathrm{H}_{2} \mathrm{SO}_{4}(2 \mathrm{M})$, then maintained in an ice bath for 1 hour. Next, $0.1 \mathrm{~mL}$ of $\mathrm{KI}-12$ was added to the tubes, which were then agitated and kept at $4^{\circ} \mathrm{C}$ for 16 hours. The KI-I 2 solution was previously prepared by diluting $15.7 \mathrm{~g}$ of iodine and $20 \mathrm{~g}$ of $\mathrm{K}$ in $100 \mathrm{~mL}$ of distilled water. The tubes were then centrifuged at 3500 rotations per minute for 15 minutes at $0^{\circ} \mathrm{C}$. The supernatant was discarded, leaving periodate crystals, which were dissolved in $4.5 \mathrm{~mL}$ of 1,2dichloroethane. Two hours and 30 minutes later absorbance was read at a wavelength of $365 \mathrm{~nm}$ in a Beckman DU 640 spectrophotometer and the glycine-betaine content was calculated.

\section{Nutritional analysis of B, Si accumulation and plant shoot dry matter production}

After analysis of oxidative stress and nonenzymatic antioxidant compounds, leaves were defrosted at ambient temperature and then washed with water, neutral detergent solution $(0.1 \%), \mathrm{HCl}$ solution $(0.1 \%)$ and deionized water. After decontamination, leaves were placed in a forced air circulation oven at $65 \pm$ $5^{\circ} \mathrm{C}$ until constant mass and then weighed. Next, the leaves were manually grinded in a crucible and mixed with the previously collected macerated plant shoot samples (branches and stems).

Shoot dry matter consisted of the leaf dry matter left over from dry matter analysis of branches and stems collected initially. After the plant material was mixed, B content was determined by a dry digestion of the samples, burning in a muffle furnace at $400^{\circ} \mathrm{C}$, followed by colorimetric reaction with azomethine-H and colorimetric spectrophotometric reading [44]. Si content was determined from an alkaline digestion of the plant material with $\mathrm{H}_{2} \mathrm{O}_{2}$ and $\mathrm{NaOH}$ in an oven at $90^{\circ} \mathrm{C}$ for $4 \mathrm{~h}$ [45], followed by colorimetric reaction with ammonium molybdate in acid medium (oxalic acid and hydrochloric acid), being then determined by colorimetric spectrophotometric readings [46].

$\mathrm{B}$ and Si accumulation were calculated as the product of B or Si content and shoot dry matter. In addition, $B$ use efficiency was calculated as the ratio between the square of plant shoot dry matter values and plant shoot B content, as described by Siddiqi and Glass [47].

\section{Statistical analysis}


The data obtained were submitted to analysis of variance (F-test), and when significant, to polynomial regression or exponential growth.

The exponential growth model was used to study polymerization. Singular models with one or two parameters were tested, and the best fit models applied, that is, those with the highest regression coefficient at $5 \%$ using the T-test.

The other variables were submitted to polynomial regression, the linear and quadratic mathematical models tested, and those with the best fit were applied. The model selection criterion established was the magnitude of significant polynomial regression coefficients at $5 \%$ probability using the T-test. When significant, the maximum and minimum points were obtained by the derivation of equations.

Statistical analyses were conducted with Sisvar ${ }^{\circledR}$ software [48] and the graphs formulated with Sigmaplot ${ }^{\circledR}$.

\section{Abbreviations}

B: Boron

GB: glycine-betaine

$\mathrm{H}_{2} \mathrm{O}_{2}$ : Hydrogen peroxide

$\mathrm{H}_{3} \mathrm{BO}_{4}$ : Boric acid

$\mathrm{K}_{2} \mathrm{O}$ : Potassium oxide

$\mathrm{KCl}$ : Potassium chloride

MDA: Malondialdehyde

$\mathrm{NaOH}$ : Sodium hydroxide

ROS: Reactive oxygen species

Si: Silicon

SiKE: Potassium silicate stabilized with sorbitol

$\mathrm{SiO}_{2}$ : Silicon dioxide

\section{Declarations}

\section{Ethics approval and consent to participate}


Not applicable

\section{Consent for publication}

Not applicable

\section{Availability of data and materials}

The datasets generated and/or analyzed during the current study are available from the corresponding author on reasonable request.

\section{Competing interests}

The authors declare that the research was conducted in the absence of any commercial or financial relationships that could be construed as a potential conflict of interest

\section{Funding}

This study was funded by Coordination for the Improvement of Higher Education Personnel (CAPES), Brazil, Code 001.

\section{Author's Contribution}

All authors have read and approved the final manuscript. JPSJ, RMP and CNSC planed and designed of the research; JPSJ and CNSC performed experiments and conducted fieldwork. JPSJ wrote the manuscript. KRO, GSSJ performed laboratorial analyses. RMP, PLG, JOC reviewed the manuscript.

\section{Acknowledgements}

The authors would like to thank the Study Group of Plant Nutrition at Unesp (Genplant) and to Leonardo Henrique Sória for the help with the graph mathematic settings.

\section{References}

1. Atique-ur-Rehman, Qamar R, Hussain A, Sardar H, Sarwar N, Javeed HMR, et al. Soil applied boron (B) improves growth, yield and fiber quality traits of cotton grown on calcareous saline soil. PLoS One. 2020;15:e0231805. doi:10.1371/journal.pone.0231805.

2. Khan MA, Wahid A, Ahmad M, Tahir MT, Ahmed M, Ahmad S, et al. World Cotton Production and Consumption: An Overview. In: Ahmad S, Hasanuzzaman M, editors. Cotton Production and Uses. Springer Singapore; 2020. p. 1-7. doi:10.1007/978-981-15-1472-2_1.

3. Wahid MA, Saleem M, Irshad S, Khan S, Cheema MA, Saleem MF, et al. Foliar feeding of boron improves the productivity of cotton cultivars with enhanced boll retention percentage. J Plant Nutr. 2020;43:2411-24. doi:10.1080/01904167.2020.1783300. 
4. Brdar-Jokanović M. Boron toxicity and deficiency in agricultural plants. Int J Mol Sci. 2020;21:1424. doi:10.3390/ijms21041424.

5. Wang G, DiTusa SF, Oh D-H, Herrmann AD, Mendoza-Cozatl DG, O'Neill MA, et al. Cross species multiomics reveals cell wall sequestration and elevated global transcript abundance as mechanisms of boron tolerance in plants. New Phytol. 2021;230:1985-2000. doi:10.1111/NPH.17295.

6. Song B, Hao X, Wang X, Yang S, Dong Y, Ding Y, et al. Boron stress inhibits beet (Beta vulgaris L.) growth through influencing endogenous hormones and oxidative stress response. Soil Sci Plant Nutr. 2019;65:346-52. doi:10.1080/00380768.2019.1617641.

7. Oliveira KR, Souza Junior JP, Bennett SJ, Checchio MV, Alves R de C, Felisberto G, et al. Exogenous silicon and salicylic acid applications improve tolerance to boron toxicity in field pea cultivars by intensifying antioxidant defence systems. Ecotoxicol Environ Saf. 2020;201:110778. doi:10.1016/j.ecoenv.2020.110778.

8. Kim Y-H, Khan AL, Waqas M, Lee I-J. Silicon regulates antioxidant activities of crop plants under abiotic-induced oxidative stress: A review. Front Plant Sci. 2017;8:510.

9. Fryzova R, Pohanka M, Martinkova P, Cihlarova H, Brtnicky M, Hladky J, et al. Oxidative stress and heavy metals in plants. In: Reviews of Environmental Contamination and Toxicology. Springer New York LLC; 2018. p. 129-56. doi:10.1007/398_2017_7.

10. Bharwana SA, Ali S, Farooq MA, Abbas F, Bioremed Biodeg J. Alleviation of lead toxicity by silicon is related to elevated photosynthesis, antioxidant enzymes suppressed lead uptake and oxidative stress in cotton. J Bioremed Biodeg. 2013;4:4. doi:10.4172/2155-6199.1000187.

11. Farooq MA, Ali S, Hameed A, Ishaque W, Mahmood K, Iqbal Z. Alleviation of cadmium toxicity by silicon is related to elevated photosynthesis, antioxidant enzymes; suppressed cadmium uptake and oxidative stress in cotton. Ecotoxicol Environ Saf. 2013;96:242-9.

12. Moldes CA, Lima Filho OF, Manuel Camiña J, Gabriela Kiriachek S, Lia Molas M, Mui Tsai S. Assessment of the effect of silicon on antioxidant enzymes in cotton plants by multivariate analysis. J Agric Food Chem. 2013;61:11243-9. doi:10.1021/jf4039088.

13. Hua T, Zhang R, Sun H, Liu C. Alleviation of boron toxicity in plants: Mechanisms and approaches. Crit Rev Environ Sci Technol. 2020. doi:10.1080/10643389.2020.1807451.

14. Ahmad R, Ali S, Abid M, Rizwan M, Ali B, Tanveer A, et al. Glycinebetaine alleviates the chromium toxicity in Brassica oleracea L. by suppressing oxidative stress and modulating the plant morphology and photosynthetic attributes. Environ Sci Pollut Res. 2020;27:1101-11. doi:10.1007/s11356-01906761-z.

15. Hamani AKM, Wang G, Soothar MK, Shen X, Gao Y, Qiu R, et al. Responses of leaf gas exchange attributes, photosynthetic pigments and antioxidant enzymes in NaCl-stressed cotton (Gossypium hirsutum L.) seedlings to exogenous glycine betaine and salicylic acid. BMC Plant Biol. 2020;20:434. doi:10.1186/s12870-020-02624-9.

16. Sun H, Luo M, Zhou X, Zhou Q, Sun Y, Ge W, et al. Exogenous glycine betaine treatment alleviates low temperature-induced pericarp browning of 'Nanguo' pears by regulating antioxidant enzymes and 
proline metabolism. Food Chem. 2020;306:125626.

17. Souza Junior JP de, Prado R de M, Sarah MM dos S, Felisberto G. Silicon mitigates boron deficiency and toxicity in cotton cultivated in nutrient solution. J Plant Nutr Soil Sci. 2019;182:805-14. doi:10.1002/jpln.201800398.

18. Carneiro-Carvalho A, Aires A, Anjos R, Martins L, Pinto T, Peixoto F, et al. The role of silicon fertilization in the synthesis of phenolic compounds on chestnut plants infected with $P$. cinnamomi and C. parasitica. J Plant Dis Prot. 2020;127:211-27. doi:10.1007/s41348-019-00292-y.

19. Liang Y, Sun W, Zhu YG, Christie P. Mechanisms of silicon-mediated alleviation of abiotic stresses in higher plants: A review. Environ Pollut. 2007;147:422-8.

20. Rady MM, Elrys AS, Abo El-Maati MF, Desoky ESM. Interplaying roles of silicon and proline effectively improve salt and cadmium stress tolerance in Phaseolus vulgaris plant. Plant Physiol Biochem. 2019;139:558-68.

21. Singh S, Singh VP, Prasad SM, Sharma S, Ramawat N, Dubey NK, et al. Interactive effect of silicon (Si) and salicylic acid (SA) in maize seedlings and their mechanisms of cadmium (Cd) Toxicity Alleviation. J Plant Growth Regul. 2019;38:1587-97. doi:10.1007/s00344-019-09958-1.

22. Zhuravlev LT. The surface chemistry of amorphous silica. Zhuravlev model. Colloids Surfaces A Physicochem Eng Asp. 2000;173:1-38. . Accessed 1 Nov 2020.

23. Souza Junior JP, de Mello Prado R, Soares MB, da Silva JLF, de Farias Guedes VH, dos Santos Sarah MM, et al. Effect of different foliar silicon sources on cotton plants. J Soil Sci Plant Nutr. 2020;:1-9. doi:10.1007/s42729-020-00345-4.

24. Peixoto M de M, Flores RA, do Couto CA, Pacheco HDN, de Mello Prado R, Souza-Junior JP, et al. Silicon application increases biomass yield in sunflower by improving the photosynthesizing leaf area. Silicon. 2020;:1-6. doi:10.1007/s12633-020-00818-2.

25. Moraes DHM, Mesquita M, Magalhães Bueno A, Alves Flores R, Elias de Oliveira HF, Raimundo de Lima FS, et al. Combined effects of induced water deficit and foliar application of silicon on the gas exchange of tomatoes for processing. Agronomy. 2020;10:1715. doi:10.3390/agronomy10111715.

26. Kubicki JD, Heaney PJ. Molecular orbital modeling of aqueous organosilicon complexes: implications for silica biomineralization. Geochim Cosmochim Acta. 2003;67:4113-21.

27. Prado R de M. Mineral nutrition of tropical plants. Springer Nature Switzerland AG; 2021.

28. Hassine AB, Ghanem ME, Bouzid S, Lutts S. An inland and a coastal population of the Mediterranean xero-halophyte species Atriplex halimus L. differ in their ability to accumulate proline and glycinebetaine in response to salinity and water stress. J Exp Bot. 2008;59:1315-26. doi:10.1093/jxb/ern040.

29. Anwar Hossain M, Hoque MA, Burritt DJ, Fujita M. Proline protects plants against abiotic oxidative stress: Biochemical and molecular mechanisms. In: Oxidative Damage to Plants: Antioxidant Networks and Signaling. Elsevier Inc.; 2014. p. 477-522.

30. Liang X, Zhang L, Natarajan SK, Becker DF. Proline mechanisms of stress survival. Antioxidants and Redox Signaling. 2013;19:998-1011. doi:10.1089/ars.2012.5074. 
31. Badran EG, Abogadallah GM, Nada RM, Nemat Alla MM. Role of glycine in improving the ionic and ROS homeostasis during NaCl stress in wheat. Protoplasma. 2015;252:835-44. doi:10.1007/s00709-014-0720-2.

32. Karabudak T, Bor M, Özdemir F, Türkan I. Glycine betaine protects tomato (Solanum lycopersicum) plants at low temperature by inducing fatty acid desaturase7 and lipoxygenase gene expression. Mol Biol Rep. 2014;41:1401-10. doi:10.1007/s11033-013-2984-6.

33. Teixeira GCM, Mello Prado R, Rocha AMS, Santos LCN, Santos Sarah MM, Gratão PL, et al. Silicon in pre-sprouted sugarcane seedlings mitigates the effects of water deficit after transplanting. J Soil Sci Plant Nutr. 2020;:1-11.

34. Detmann KC, Araújo WL, Martins SCV, Sanglard LMVP, Reis J V., Detmann E, et al. Silicon nutrition increases grain yield, which, in turn, exerts a feed-forward stimulation of photosynthetic rates via enhanced mesophyll conductance and alters primary metabolism in rice. New Phytol. 2012;196:752-62. doi:10.1111/j.1469-8137.2012.04299.x.

35. Singh A, Roychoudhury A. Silicon-regulated antioxidant and osmolyte defense and methylglyoxal detoxification functions co-ordinately in attenuating fluoride toxicity and conferring protection to rice seedlings. Plant Physiol Biochem. 2020;154:758-69.

36. Barros TC, de Mello Prado R, Roque CG, Arf MV, Vilela RG. Silicon and salicylic acid in the physiology and yield of cotton. J Plant Nutr. 2019;42:458-65.

37. Noreen S, Fatima Z, Ahmad S, Athar H-R, Ashraf M. Foliar application of micronutrients in mitigating abiotic stress in crop plants. Plant Nutr Abiotic Stress Toler. 2018;:95-117. doi:10.1007/978-981-109044-8_3.

38. Hoagland DR, Arnon DI. The water-culture method for growing plants without soil. 1950.

39. Görmüs Ö. Interactive effect of nitrogen and boron on cotton yield and fiber quality. Turkish Journal of Agriculture and Forestry. 2005;29:51-9.

40. Gratão PL, Monteiro CC, Carvalho RF, Tezotto T, Piotto FA, Peres LEP, et al. Biochemical dissection of diageotropica and Never ripe tomato mutants to Cd-stressful conditions. Plant Physiol Biochem. 2012;56:79-96.

41. Alexieva V, Sergiev I, Mapelli S, Karanov E. The effect of drought and ultraviolet radiation on growth and stress markers in pea and wheat. Plant, Cell Environ. 2001;24:1337-44.

42. Bates LS, Waldren RP, Teare ID. Rapid determination of free proline for water-stress studies. Plant Soil. 1973;39:205-7.

43. Grieve CM, Grattan SR. Rapid assay for determination of water soluble quaternary ammonium compounds. Plant Soil. 1983;70:303-7. doi:10.1007/BF02374789.

44. Bataglia $O$ c., Teixeira JPF, Furlani PR, Furlani AMC, Gallo JR. Métodos de análise química de plantas [Methods of chemical analysis of plants]. Campinas; 1983.

45. Kraska JE, Breitenbeck GA. Simple, robust method for quantifying silicon in plant tissue. Commun Soil Sci Plant Anal. 2010;41:2075-85. 
46. Kondörfer GH, Pereira HS, Nola A. Análise de silício: solo, planta e fertilizante [Silicon analyse: soil, plant and fertilizers]. Uberlândia; 2004.

47. Siddiqi MY, Glass ADM. Utilization index: A modified approach to the estimation and comparison of nutrient utilization efficiency in plants. J Plant Nutr. 1981;4:289-302.

doi:10.1080/01904168109362919.

48. Ferreira DF. Sisvar: a guide for its bootstrap procedures in multiple comparisons. Ciência e Agrotecnologia. 2014;38:109-13.

Figures

a)

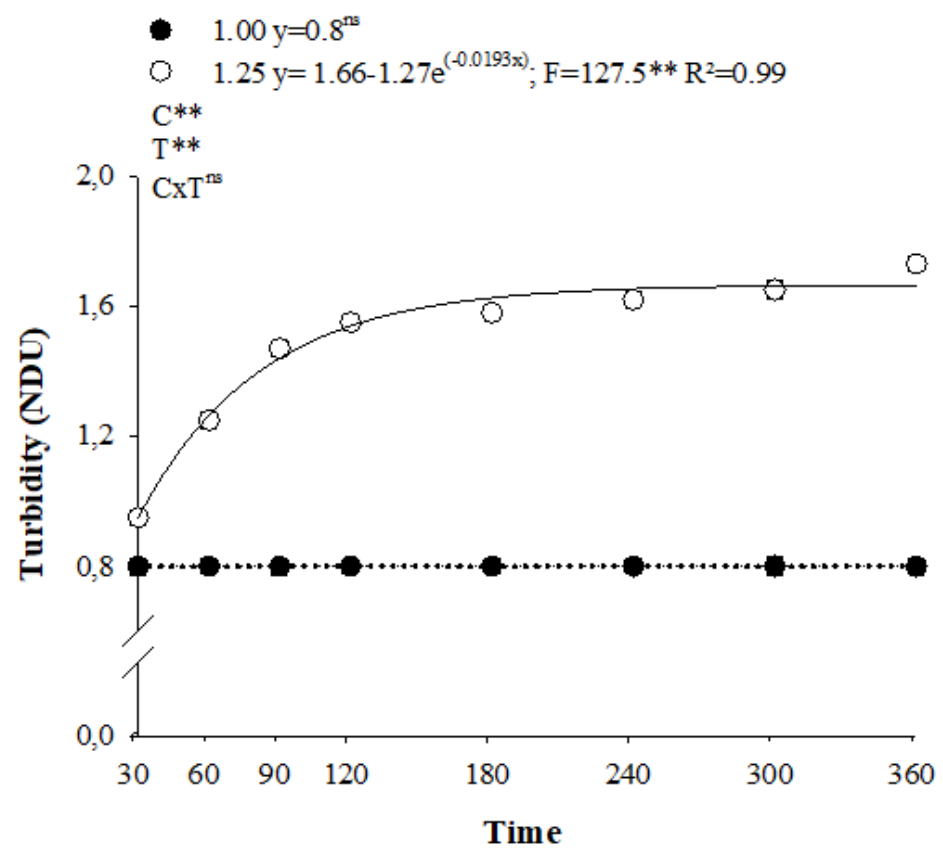

b)

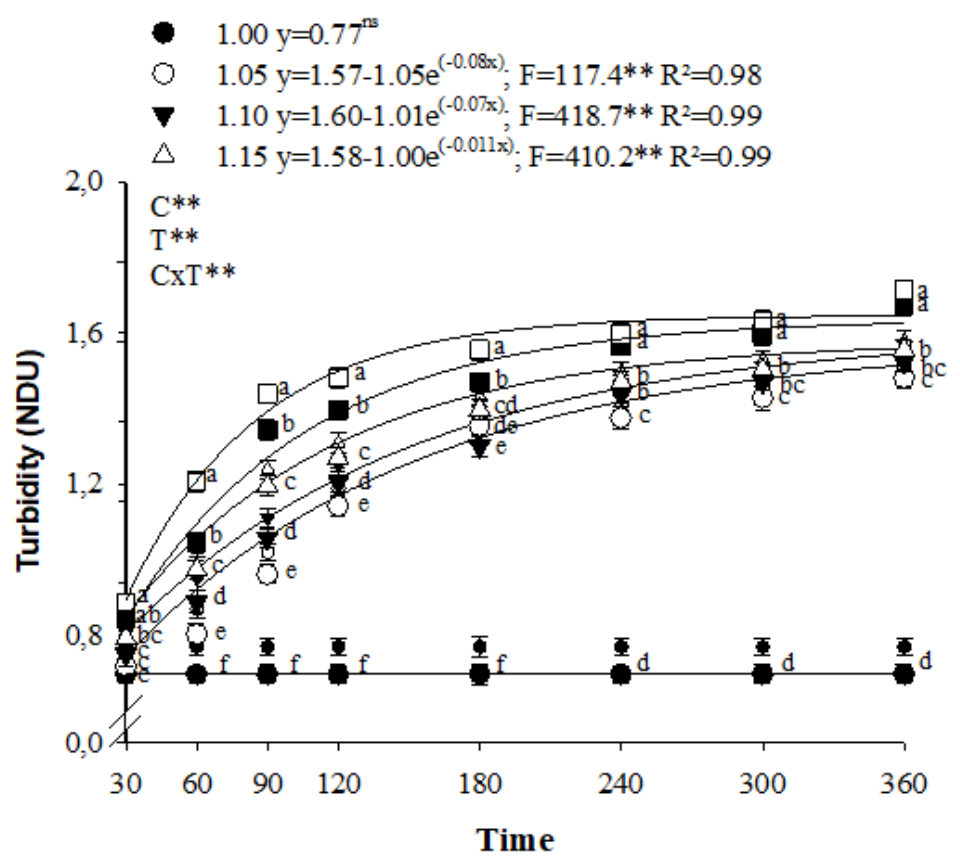

\section{Figure 1}

Turbidity index of the boron $\left(2.5 \mathrm{~g} \mathrm{~L}^{-1}\right)+$ silicon $\left(1.00\right.$ and $\left.1.25 \mathrm{~g} \mathrm{~L}^{-1}\right)$ (a); and boron $\left(2.5 \mathrm{~g} \mathrm{~L}^{-1}\right)+$ silicon mixture $\left(1.00 ; 1.05 ; 1.10 ; 1.15 ; 1.20\right.$ and $\left.1.25 \mathrm{~g} \mathrm{~L}^{-1}\right)$ as a function of time after solution preparation. 


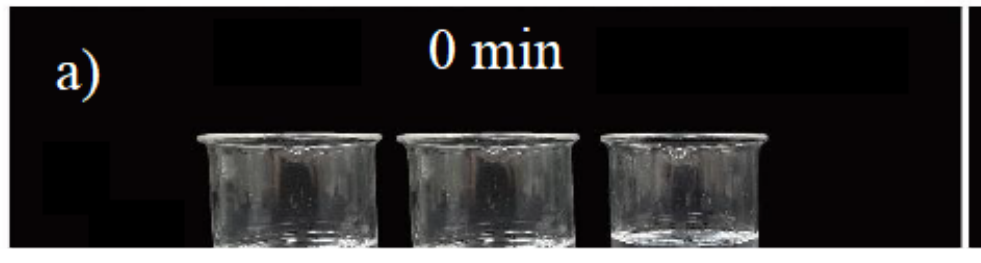

\section{Figure 2}

Assessment of the visual colorimetric change in the boron $\left(2.50 \mathrm{~g} \mathrm{~L}^{-1}\right)+$ silicon mixture $(1.00 ; 1.25$ and $1.50 \mathrm{~g} \mathrm{~L}^{-1}$ ) immediately (a) and $360 \mathrm{~min}$ after solution preparation (b); and boron ( $\left.2.50 \mathrm{~g} \mathrm{~L}^{-1}\right)+$ silicon mixture $\left(1.00 ; 1.05 ; 1.10 ; 1.15 ; 1.20\right.$ and $\left.1.25 \mathrm{~g} \mathrm{~L}^{-1}\right)$ at $0(\mathrm{c}) ; 60(\mathrm{~d}) ; 120(\mathrm{e}) ; 180(\mathrm{f}) ; 300(\mathrm{~g})$ and $360(\mathrm{~h})$ min after solution preparation. 
a)

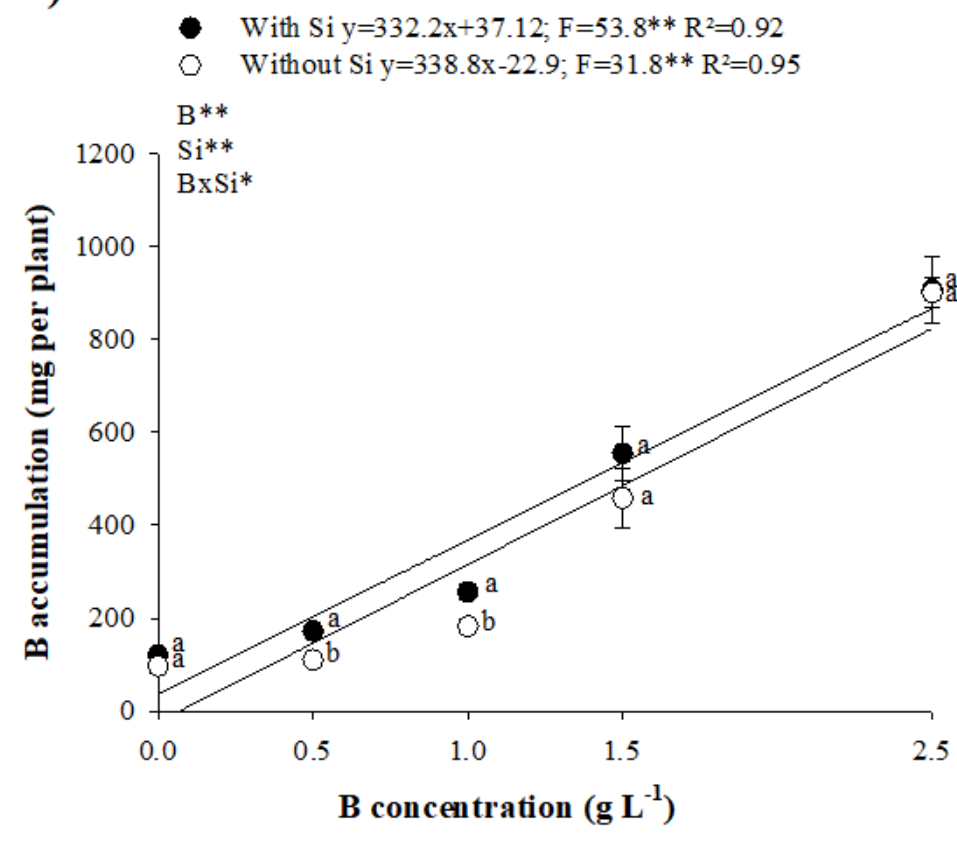

b)

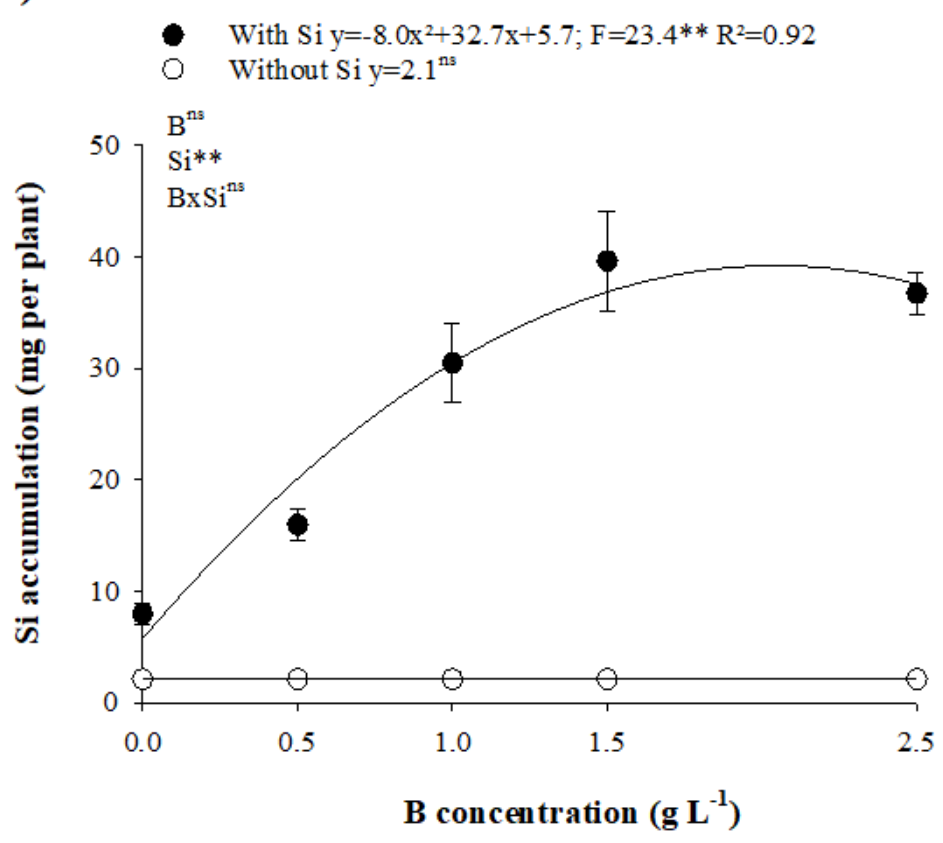

\section{Figure 3}

Shoot boron (a) and silicon accumulation (b) in B-deficient cotton plants as a function of different leaf boron $(\mathrm{B})$ and silicon (Si) concentrations.

\section{Figure 4}

Hydrogen peroxide $\left(\mathrm{H}_{2} \mathrm{O}_{2}\right)(a)$, malondialdehyde (MDA) (b), proline (c) and glycine-betaine (d) production in B-deficient cotton plants as a function of different leaf boron (B) and silicon (Si) concentrations. 
a)

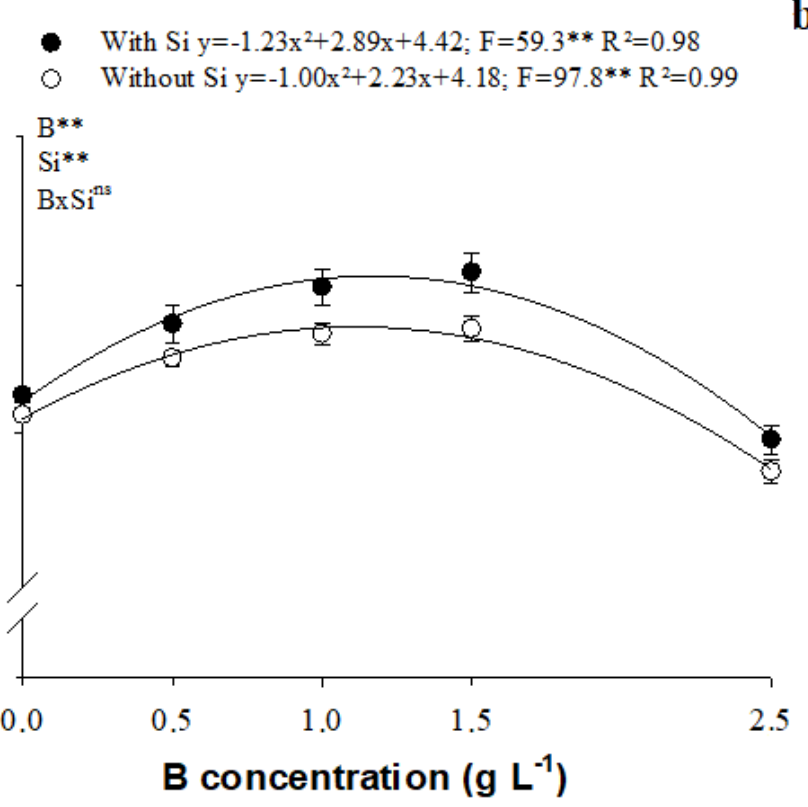

b)

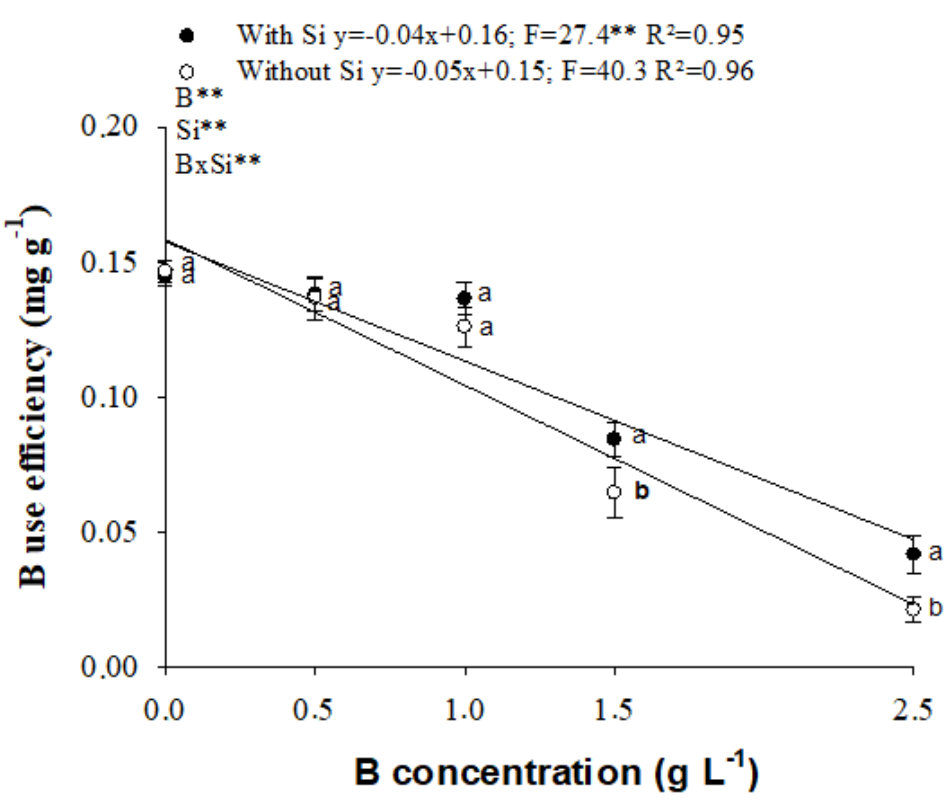

\section{Figure 5}

Shoot dry weight (a) and boron use efficiency (b) in B-deficient cotton plants as a function of different leaf boron (B) and silicon (Si) concentrations.

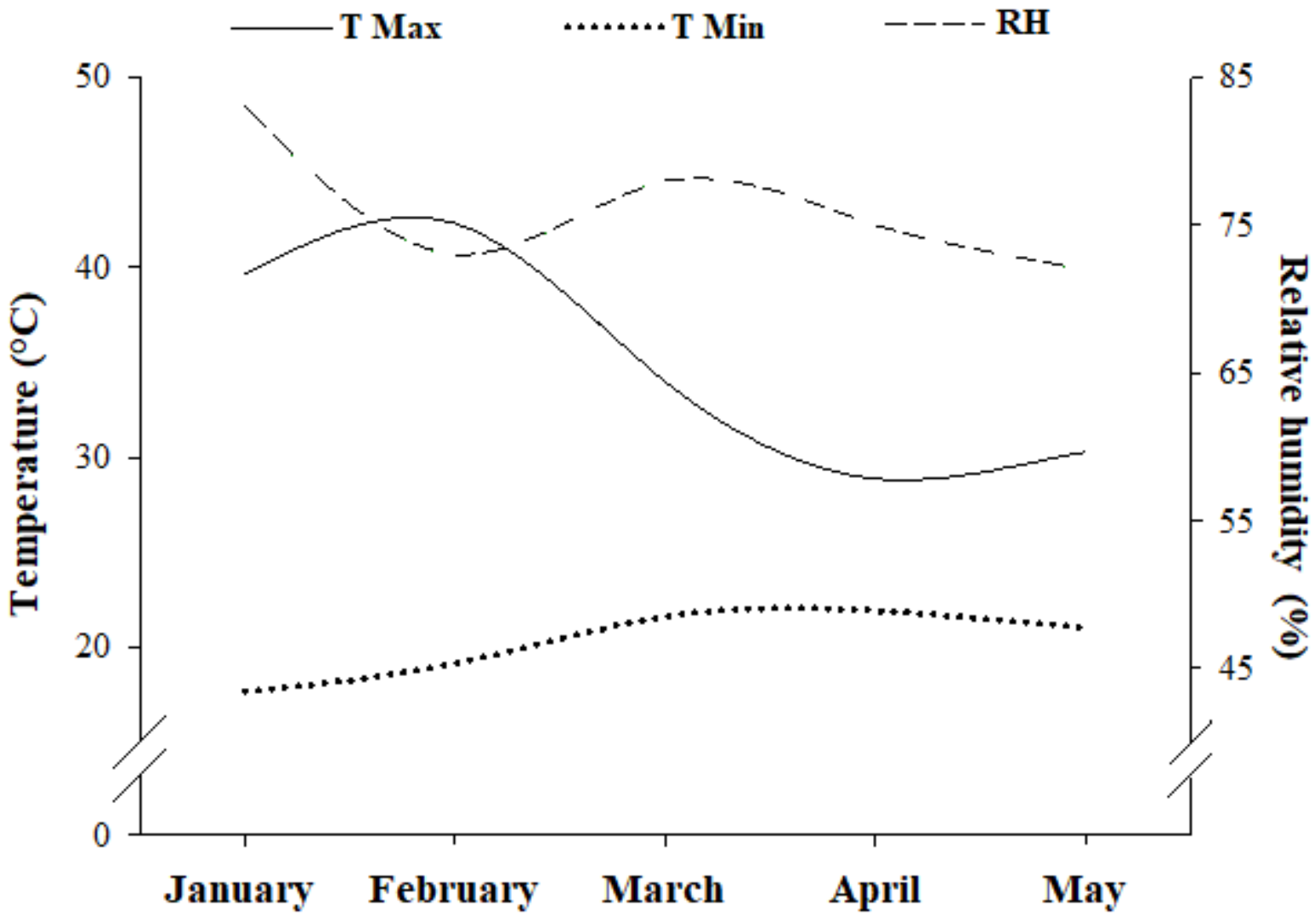

Figure 6 
Maximum ( $T$ Max) and minimum temperature ( $T$ Min) and relative humidity $(\mathrm{RH})$ in the greenhouse during the experimental period. 